\title{
Technical note: Development of a challenge model for Streptococcus uberis mastitis in dairy heifers
}

\author{
K. A. Jackson, ${ }^{\star}$ S. C. Nickerson, ${ }^{\star 1}{ }^{1}$ F. M. Kautz, ${ }^{*}$ and D. J. Hurley† \\ *Department of Animal and Dairy Science, and \\ †Department of Population Health, College of Veterinary Medicine, University of Georgia, Athens 30602
}

\section{ABSTRACT}

A challenge model for experimentally inducing Streptococcus uberis mastitis in bred dairy heifers was developed. Qualifying heifers $(\mathrm{n}=7)$ exhibited antibody titers of $<1: 10,000$ against Strep. uberis antigens and were free of intramammary infections (IMI). Two contralateral quarters of each heifer were assigned to receive an infusion of Strep. uberis (1,000 to 2,000 cfu); remaining quarters served as unchallenged controls. For a successful challenge and infection, 3 of 4 consecutive mammary secretion samples had to culture positive for Strep. uberis. Six of the 7 heifers were challenged successfully in both infused quarters with a mean dose of $1,080 \mathrm{cfu}$; once confirmed, infections were treated with a one-time infusion of nonlactating cow therapy. Before challenge, mammary secretion leukocyte counts averaged $8.4 \times 10^{6} / \mathrm{mL}$ in all quarters. At $24 \mathrm{~h}$ after challenge, leukocyte count increased to $18.4 \times 10^{6} / \mathrm{mL}$ in challenged quarters, peaking on d 5 at $24.3 \times 10^{6} /$ $\mathrm{mL}$; unchallenged quarters remained at $\leq 10.4 \times 10^{6} /$ $\mathrm{mL}$, but increased to $15.2 \times 10^{6} / \mathrm{mL}$ on $\mathrm{d} 7$ and then decreased. Before challenge, macrophages predominated $(81 \%)$ in mammary secretions followed by lymphocytes (15.3\%) and neutrophils (3.7\%). By $24 \mathrm{~h}$ after challenge, neutrophils increased in challenged quarters and predominated for the duration of the trial (65.3 to $70 \%$ ), whereas macrophages predominated in unchallenged control quarters (65.2 to $75.2 \%$ ). The challenge model was successful in establishing Strep. uberis IMI in $85.7 \%$ of animals, and IMI were controlled $(100 \%$ cure) by administering nonlactating cow therapy. All heifers calved free of IMI and antimicrobial residues, with milk production similar to that of herd mates and with somatic cell counts (SCC) $<200,000$ cells $/ \mathrm{mL}$.

Key words: challenge model, heifer, mastitis, Streptococcus uberis

Received May 29, 2012.

Accepted August 30, 2012.

${ }^{1}$ Corresponding author: scn@uga.edu

\section{Technical Note}

Streptococcus uberis mastitis may be prevalent in heifers during the prepartum period and can be cured with nonlactating cow therapy (Owens et al., 1994). However, no vaccines are currently commercially available to prevent new IMI with this major pathogen. Several experimental Strep. uberis vaccines have been formulated, and the purpose of this study was to develop a Strep. uberis challenge model as a prelude to evaluating new Strep. uberis vaccine candidates. If vaccines prove efficacious, immunization could be used as a management tool to help control these environmental pathogens and ensure that heifers calve free of IMI.

Seven bred Holstein heifers 23 to 26 mo of age from the University of Georgia Teaching Dairy (Athens) were used. To qualify, each heifer was required to exhibit a serum antibody titer of $<1: 10,000$ against whole-cell Strep. uberis CAMP and gapC antigens and be diagnosed free of IMI. The antigens CAMP and GapC have been identified as functional virulence determinants in the pathogenesis of Strep. uberis mastitis. The CAMP antigen inhibits phagocytosis by blocking immunoglobulin Fc-binding sites, and GapC provides significant protection against Strep. dysgalactiae infection in dry cows (Fontaine et al., 2002).

Study days for this challenge trial were as follows: $\mathrm{d}-7$ : heifers were screened to ensure that a new IMI had not developed in quarters to be challenged; d 0 : heifers were challenged in 2 mammary quarters with Strep. uberis; d 1, 5, 7, and 9: mammary secretions were collected for microbiological culture and total and differential leukocyte counts; d 9: quarters with confirmed Strep. uberis IMI were treated $1 \times$ with nonlactating cow therapy. The use of dairy cattle in this trial was approved by the University of Georgia Institutional Animal Care and Use Committee.

On d 0 , the 7 heifers were assigned 2 contralateral quarters to receive Strep. uberis challenge as follows: a bacterial suspension was created to achieve a concentration of 1,000 to $2,000 \mathrm{cfu} / \mathrm{mL}$ in $1 \mathrm{~mL}$ of sterile PBS, which was loaded into a tuberculin syringe and administered aseptically via a cannula into the teat 
canal. Teat ends were then dipped in a $1 \%$ iodine teat dip (FS-103 X, IBA Inc., Millbury, MA). To determine if a heifer was challenged successfully, 3 of 4 consecutive microbiological cultures collected post-challenge from each infused quarter had to be positive for Strep. uberis based on procedures recommended by the National Mastitis Council (1999), followed by species-level identification using the Slidex Strepto Plus test (bioMérieux, Marcy l'Étoile, France) plus the API 20 Strep identification system (bioMérieux).

Heifers were monitored daily for general health, rectal temperature, and visual inflammation of the mammary gland. Once an IMI was confirmed, the challenged quarter was treated with a one-time infusion of nonlactating cow therapy (Spectramast DC, ceftiofur hydrochloride intramammary antibiotic, Pfizer Animal Health, New York, NY). All experimental IMI were confirmed by d 9 ; that is, challenged quarters were culture positive on $\mathrm{d} 1,3$, and 5 . Thus, on d 9 , mammary secretions were collected for culture and then nonlactating cow therapy was administered. Because heifers were in the last trimester of pregnancy, quarters with confirmed IMI needed to be treated promptly and well before calving to effect a cure and to avoid antibiotic residues in milk.

Mammary secretions collected post-challenge were used to estimate total and differential leukocyte cell counts to demonstrate any inflammatory response in challenged and control quarters. Because of the viscosity and turbidity of secretions, a hemacytometer was used for total leukocyte counts. Secretions were diluted 1:10 to 1:30 with PBS, depending on the viscosity of the sample, mixed by vortexing, and centrifuged at 900 $\times g$ for 15 min to produce a pellet. The supernatant was removed and the pellet was suspended in 10 times its packed volume with PBS. This solution was then further diluted 1:10 in trypan blue, a leukocyte count was performed using a hemacytometer, and final counts were adjusted based on dilutions made.

The suspension used for the total leukocyte count was further diluted to approximately $2 \times 10^{6}$ cells/ $\mathrm{mL}$ using PBS. A 1-mL volume of this suspension was pipetted into a $1.5-\mathrm{mL}$ microfuge tube, and flow analysis was conducted using the bovine "flow differential" template based on forward angle and side light scatter (size and granularity, respectively) on an Accuri C6 flow cytometer (Accuri Cytometers, Ann Arbor, MI).

To determine differential leukocyte counts, a $\mathrm{Cy}$ tospin 2 centrifuge was used (Shandon-Southern, Cheshire, UK) to prepare smears on microscope slides, which were stained with eosin/crystal violet. Smears were analyzed using a standard light microscope (Meiji MX5300L Biological Microscope, Martin Microscope Company, Easley, SC) with the oil immersion lens. The percentages of lymphocytes, monocytes, and neutro- phils were determined for secretions from each quarter by counting 100 leukocytes on each cell smear/quarter at $1,000 \times$ magnification.

The SAS software (SAS Institute Inc., Cary, NC) was used to determine the effects of intramammary challenge on several variables. Frequencies of total leukocyte counts, differential leukocyte counts, and results of flow cytometry were analyzed to determine if differences existed between challenged quarters and unchallenged controls.

Six of the 7 heifers $(85.7 \%)$ were challenged successfully with the Strep. uberis dose used. The average concentration used to challenge the 7 heifers was 1,080 cfu/ $\mathrm{mL}$, which fell within the goal of 1,000 to $2,000 \mathrm{cfu} /$ $\mathrm{mL}$. Previous studies have used artificial challenge with mastitis-causing bacteria to induce IMI in adult cows across a wide range of challenge doses. For example, Paape et al. (1988) inoculated 250 cfu of Strep. uberis intracisternally into lactating cows, which was $70 \%$ successful in developing IMI. Nickerson et al. (1990) challenged the mammary glands of heifers intracisternally with 565 cfu of Strep. uberis, which was more than twice the dose used by Paape et al. (1988) but only $42.9 \%$ successful in developing IMI. Bolton et al. (2004) used a slightly higher dose of Strep. dysgalactiae and infused $650 \mathrm{cfu} / \mathrm{mL}$ into 72 quarters of 24 Holstein cows during the dry period, and found that $45 \%$ of quarters were successfully challenged. Similar to the dose used in the present study, Leigh et al. (1999) challenged lactating cows in 2 quarters with 1,000 cfu of Strep. uberis strain 0140J and established infections in $95.7 \%$ of quarters, a rate similar to that observed in the present trial.

All heifers that were successfully challenged showed clinical signs of mastitis at some point during the trial. This was similar to the results of Nickerson et al. (1990), who recorded clinical symptoms in $100 \%$ of the cows challenged with Strep. uberis after being fitted with 5 different intramammary device models. Similarly, Hill (1988) observed clinical symptoms in $100 \%$ of the dry cows that were successfully challenged with Strep. uberis. Leigh et al. (1999) also observed that all quarters that shed Strep. uberis after challenge exhibited clinical signs of disease. Likewise, Finch et al. (1997) observed clinical symptoms within $24 \mathrm{~h}$ after challenging cows with Strep. uberis.

Total leukocyte counts across all quarters of all heifers 1 wk before challenge $(\mathrm{d}-7)$ averaged $8.1 \times 10^{6} / \mathrm{mL}$ : $9.9 \times 10^{6} / \mathrm{mL}$ for control quarters and $6.3 \times 10^{6} / \mathrm{mL}$ for quarters destined for challenge (Figure 1). At $24 \mathrm{~h}$ post-challenge (d 1), average leukocyte count increased to $18.4 \times 10^{6} / \mathrm{mL}$ in challenged quarters, peaking at $24.3 \times 10^{6} / \mathrm{mL}$ on $\mathrm{d} 5$, and then decreasing to 15.7 and $10.5 \times 10^{6} / \mathrm{mL}$ on $\mathrm{d} 7$ and 9 , respectively. In unchallenged control quarters, counts decreased to $2.8 \times 10^{6} /$ 


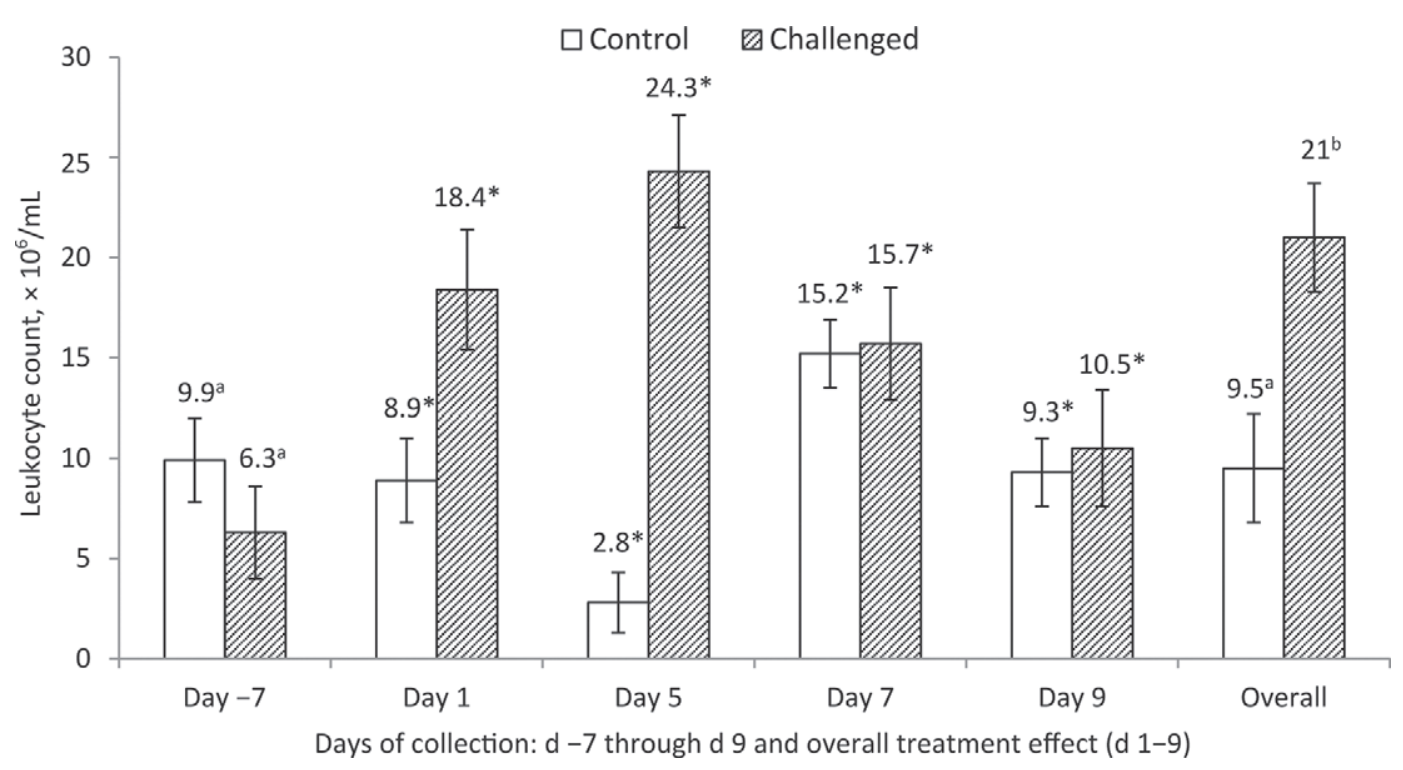

Figure 1. Average leukocyte counts $\left(\times 10^{6} / \mathrm{mL}\right) \pm$ standard errors in mammary secretions of control and challenged quarters before challenge

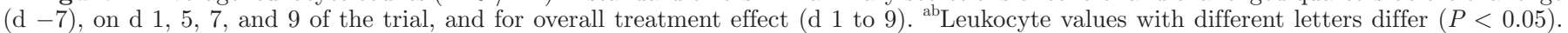
*Because of missing values, leukocyte counts on d 1,5, 7, and 9 could not be statistically analyzed for differences between control and challenged quarters; however, overall treatment effect (d 1 to 9 ) was tested.

$\mathrm{mL}$ on $\mathrm{d} 5$ and then increased to $15.2 \times 10^{6} / \mathrm{mL}$ and $9.3 \times 10^{6} / \mathrm{mL}$ on $\mathrm{d} 7$ and 9 , respectively. The overall treatment effect of combining d 1 through 9 showed a significant $(P<0.05) 2$-fold increase in the leukocyte count of challenged quarters: $21 \times 10^{6} / \mathrm{mL}$ versus 9.5 $\times 10^{6} / \mathrm{mL}$.

Total leukocyte counts in the current study showed a marked increase in challenged quarters $\left(24.3 \times 10^{6} / \mathrm{mL}\right)$ compared with control quarters $\left(2.8 \times 10^{6} / \mathrm{mL}\right)$ on $\mathrm{d}$ 5 after introduction of bacteria. Such 8.5-fold increases were similar to results of Nickerson et al. (1990), who showed an 8.3-fold elevation in SCC after challenging quarters of lactating cows with Strep. uberis. Likewise, Leigh et al. (1999) and Hill (1988) found that SCC increased up to $10 \times 10^{6} / \mathrm{mL}$ after challenging lactating cows with Strep. uberis. Thus, the maximum total leukocyte count observed in the present trial was in line with those of previous studies and confirms the establishment of infection.

Differential leukocyte counts across all quarters of all heifers showed that before challenge $(\mathrm{d}-7)$, macrophages predominated $(81 \%)$ followed by lymphocytes $(15.3 \%)$ and neutrophils $(3.7 \%)$, and were similar to those found by Trinidad et al. (1990), who demonstrated the following percentages: $90 \%$ macrophages, $7 \%$ lymphocytes, and 3\% neutrophils for uninfected quarters of heifers. Likewise, Quiroga et al. (1993) found that macrophages were predominant $(>90 \%)$ in secretions collected from uninfected quarters of heifers.
In unchallenged quarters, macrophages remained the predominant leukocyte type, ranging between 65.2 and $73.2 \%$ for the duration of the trial, but in challenged quarters (Figure 2), neutrophils increased (46.1\%) at the expense of macrophages and lymphocytes by $24 \mathrm{~h}$ after bacterial inoculation (d 1). After d 1, neutrophils remained the major cell type and ranged between 65.3 and $77 \%$ for the duration of the trial. The overall treatment effect demonstrated decreases in the percentages of macrophages and lymphocytes and an increase in the percentage of neutrophils in challenged quarters compared with controls throughout the trial $(P<0.05)$. Thus, as the percentage of neutrophils increased in challenged quarters in response to Strep. uberis IMI, we observed concomitant decreases in percentages of macrophages and lymphocytes, whereas, in control quarters, leukocyte populations remained stable, suggesting that the response to challenge via an influx of neutrophils was localized in challenged quarters without affecting adjacent unchallenged quarters. Neutrophils enter the infected mammary gland in large numbers in attempts to phagocytize and eliminate infecting bacteria (Paape et al., 1988).

Flow cytometry confirmed the results observed above with differential leukocyte counting by light microscopy. Before challenge, mammary secretions were composed of predominantly agranular cells (macrophages and lymphocytes), averaging $51.1 \%$ across challenged and control quarters, whereas granular cells (neutrophils) 


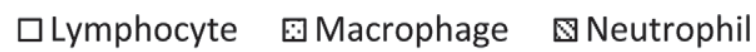

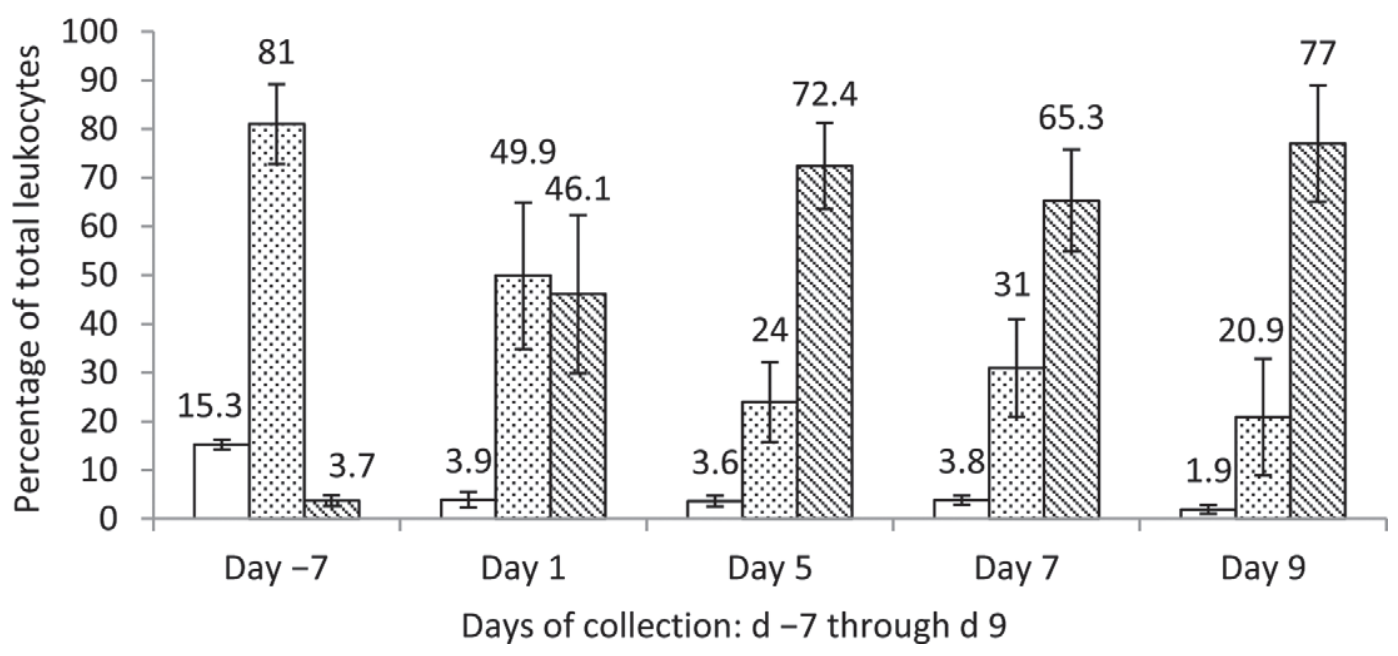

Figure 2. Mean differential leukocyte counts \pm standard errors in mammary secretions of challenged quarters before challenge $(\mathrm{d}-7)$ and on $\mathrm{d} 1,5,7$, and 9 of the trial.

made up $24.3 \%$ of the leukocyte population. At $24 \mathrm{~h}$ post-inoculation in challenged quarters, granular cells increased to $54.8 \%$ and peaked on d $5(56 \%)$, decreasing to $35 \%$ by d 9 . Agranular cell populations decreased to $28.2 \%$ on d 1 and remained at this level on d 5, 7, and 9 , ranging from 28.2 to $31 \%$. The mean percentage of granular cells across d 1 to 9 was higher in challenged quarters $(54.4 \%)$ than in controls $(32.3 \% ; P<0.05)$, and the mean percentage of agranular cells across $d$ 1 to 9 was lower in challenged quarters $(31 \%)$ than in controls $(51 \% ; P<0.05)$.

After confirmation of Strep. uberis IMI, quarters were treated with nonlactating cow therapy approximately $30 \mathrm{~d}$ before expected calving date. All heifers calved free of IMI and, by $10 \mathrm{~d}$ post-calving, all quarters exhibited SCC $<200,000 / \mathrm{mL}$. Individual quarter samples, as well as composite samples, were negative for antimicrobial residues, and milk production of the 7 study heifers ( $\operatorname{mo} 1=35.7 \mathrm{~kg} ;$ mo $2=34.2 \mathrm{~kg}$ ) was similar to that of herd mates (mo $1=39.1 \mathrm{~kg}$; mo $2=34.3 \mathrm{~kg}$ ).

The intramammary challenge model developed was successful in establishing experimental Strep. uberis mastitis in dairy heifers during late pregnancy, which was controlled ( $100 \%$ cure) by the administration of nonlactating cow therapy. This model will be instrumental in evaluating the immune response of dairy cattle by providing a reproducible bacterial challenge of the mammary gland to assess protective immunity developed in heifers immunized against Strep. uberis vaccine antigens.

\section{REFERENCES}

Bolton, A., X. M. Song, P. Willson, M. C. Fontaine, A. Potter, and J. Perez-Casal. 2004. Use of the surface proteins GapC and Mig of Streptococcus dysgalactiae as potential protective antigens against bovine mastitis. Can. J. Microbiol. 50:423-432.

Finch, J. M., A. Winter, A. W. Walton, and J. A. Leigh. 1997. Further studies on the efficacy of a live vaccine against mastitis caused by Streptococcus uberis. Vaccine 15:1138-1143.

Fontaine, M. C., J. Perez-Casal, X. Song, J. Shelford, P. J. Willson, and A. A. Potter. 2002. Immunisation of dairy cattle with recombinant Streptococcus uberis GapC or a chimeric CAMP antigen confers protection against heterologous bacterial challenge. Vaccine 20:2278-2286.

Hill, A. W. 1988. Pathogenicity of two strains of Streptococcus uberis infused into lactating and non-lactating bovine mammary glands. Res. Vet. Sci. 45:400-404.

Leigh, J. A., J. M. Finch, T. R. Field, N. C. Real, A. Winter, A. W Walton, and S. M. Hodgkinson. 1999. Vaccination with the plasminogen activator from Streptococcus uberis induces an inhibitory response and protects against experimental infection in the dairy cow. Vaccine 17:851-857.

National Mastitis Council. 1999. Laboratory Handbook on Bovine Mastitis. National Mastitis Council Inc., Madison, WI.

Nickerson, S. C., R. L. Boddie, W. E. Owens, and J. L. Watts. 1990. Effects of novel intramammary device models on incidence of mastitis after experimental challenge. J. Dairy Sci. 73:2774-2784.

Owens, W. E., S. C. Nickerson, P. J. Washburn, and C. H. Ray. 1994. Antibiotic therapy of intramammary infections in bred dairy heifers. Louisiana Agric. 37:20-22.

Paape, M. J., W. D. Schultze, N. J. Cortlett, and B. T. Weinland. 1988. Effect of abraded intramammary device on outcome in lactating cows after challenge exposure with Streptococcus uberis. Am. J. Vet. Res. 49:790-792.

Quiroga, G., W. E. Owens, and S. C. Nickerson. 1993. Response of heifer mammary gland macrophages and neutrophils to interferongamma stimulation in vitro. Can. J. Vet. Res. 57:212-214.

Trinidad, P., S. C. Nickerson, T. K. Alley, and R. W. Adkinson. 1990. Efficacy of intramammary treatment of unbred and primigravid dairy heifers. J. Am. Vet. Med. Assoc. 197:465-470. 